\title{
Quantitative analysis, distributional pattern and species diversity of woody plant species of Lamberi Forest Range, Rajouri, J\&K, India
}

\author{
Jyoti Sharma and Anil K. Raina* \\ Department of Environmental Sciences, University of Jammu, Jammu-180006 (J\&K), INDIA \\ *Corresponding author. Email: anilkraina@yahoo.com \\ Received: November 24, 2017; Revised received: January 20, 2018; Accepted: February 27, 2018
}

\begin{abstract}
Quantitative analysis, distributional pattern and species diversity of woody plant species of Lamberi Range of Rajouri Forest division, J\&K, has been carried out by laying 50 quadrats $(10 \mathrm{~m} \times 10 \mathrm{~m}$ size) for trees and 100 quadrats $(5 \mathrm{~m} \times 5 \mathrm{~m}$ size) for shrubs. Various phytosociological parameters like frequency, density, abundance, importance value index IVI and diversity indices for trees and shrubs has been used to reveal the plant community structure of the area. The abundance to frequency ratio (A/F) for different species was determined to assess the distribution pattern of the species (regular $<0.025$, random $0.025-0.05$ and contagious $>0.05$ ) which indicated the contagious distribution for all the species. Survey of the area revealed presence of 63 woody plant species from the study area comprising of 43 trees and 20 shrubs. Pinus roxburghii (IVI 49.7, Abundance 81.1) and Carissa opaca (IVI 81.12 abundance 7.05) have been recorded as the dominant tree and shrub, respectively, of the area. The computation of diversity indices showed that species richness and evenness i.e Shannon- Weiner's, Margalef's and Menhinick's remained high for trees and low for shrubs. Simpson's index of dominance was also high for trees. Species which needs priorities for conservation and protection and also required to be monitored have also been highlighted.
\end{abstract}

Keywords: Distributional pattern, Lamberi forest range, Phytosociology, Species diversity, Woody vegetation

\section{INTRODUCTION}

The prime objective of the quantitative analysis of vegetation, also known as phytosociology, is to describe the vegetation, explain or predict its pattern and classify it in a meaningful way (Ilorkar and Khatri, 2003). It indicates species diversity which determines the distribution of individuals among the species in a particular habitat. The species diversity and distribution pattern are useful for the evaluation of ecological significance of an ecosystems (Ardakani, 2004; Reddy and Ugle, 2008). The structure and composition, most significant ecological attributes of an ecosystem, exhibit variations in response to environmental as well as anthropogenic variables (Timilsina et al., 2007; Gairola et al., 2008; Shaheen et al., 2012). Various diversity indices, used as indicators of the degree of complexity of the communities, provide information on the homeostatic capacity of the system to unforeseen environmental changes (Magurran, 1988).

Vegetation of Himalaya is diverse and distributed over a wide range of climatic and topographical variation (Dhaulkhandi et al., 2008). Several workers have studied the phytosociological parameters and population structure of forests in Himalayan subtropical regions (Ahmed et al., 2006; Kharkwal, 2009; Rawat and Chandhok, 2009; Kharkwal and Rawat, 2010; Gurarni et al.,2010; Gairola et al.,2011; Shaheen et al.,2011). In Jammu region of $\mathrm{J} \& \mathrm{~K}$ state, studies on phytosociological investigation, phytodiversity assessment and distribution pattern has also been carried out by the workers like Kour (2001) in Trikuta hills; Sudan (2007) in Mahamaya catchment; Sharma et al., (2008) in Birhun watershed; Dangwal et al. (2012) in Nowshera and Sharma and Raina (2013) in Jammu, however the work on this aspect in the Lamberi Forest Range of district Rajouri has not been done so far. Therefore, the present work has been carried out to document the species diversity and dominance in Lamberi Forest Range which falls under inner Shiwaliks region in Nowshera Forest Division of district Rajouri, J\&K, India.

\section{MATERIALS AND METHODS}

Vegetation analysis: Lamberi Forest Range falls under inner Shiwaliks region in Nowshera Forest Division $\left(33^{\circ} 06^{\prime} \mathrm{N}\right.$ to $33^{0} 13^{\prime} \mathrm{N}$ and $74^{\circ} 08^{\prime} \mathrm{E}$ to $\left.74^{0} 18^{\prime} \mathrm{E}\right)$ of district Rajouri, J\&K, India. It covers an altitudinal range of $600 \mathrm{~m}$ to $1200 \mathrm{~m}$ above sea level .s.l and falls mostly in sub-tropical zone with an average maximum and minimum temperature of $37.4^{\circ} \mathrm{C}$ to $7.42^{0} \mathrm{C}$, respectively. Average annual rainfall is $500 \mathrm{~mm}$, most of which occurs during monsoon season. 
Thorough field visits have been conducted from May 2011 to June 2012 to survey all the possible habitats for recording the data. For the purpose of identification of the plants, various local, regional and National flora has been used besides consulting taxonomic experts of the region.. Data on Phytosociological attributes of plant species has been collected by randomly laying 50 quadrats of $10 \mathrm{~m} \times 10 \mathrm{~m}$ size for trees and 100 quadrats of $5 \mathrm{~m} \times 5 \mathrm{~m}$ size for shrubs in forest area.

Data analysis: The recorded data was quantitatively analysed for density, frequency and abundance following Curtis and McIntosh (1950). In order to have a overall picture of ecological importance of species with respect to the community structure, the percentage values of the relative frequency, relative density and relative dominance have been determined as Phillips (1959) which have been added together to get the Importance Value Index(I.V.I ) of individual species (Curtis, 1959). In each quadrat, all plants having cbh $\geq$ $30 \mathrm{~cm}$ were treated as trees and individually measured at breast height, i.e. $1.37 \mathrm{~m}$ from the ground.

The basal area was calculated by using following formula.

${\underline{(\mathrm{Cbh})^{2}}}^{2}$

$(4 \pi)$

Where, $c b h=$ circumference at breast height(meters)

The ratio of abundance to frequency (A/F) for different species was determined to assess the distribution pattern (Curtis and Cotton, 1956). Species diversity and concentration of dominance was computed by using Shannon-Weiner index (Shannon and Weiner, 1949) and Simpson index (Simpson,1949), respectively. Species richness was calculated by using Menhinick's Index (Menhinick, 1964) and Margalef's Index (Margalef,1968).

\section{RESULTS AND DISCUSSION}

The perusal of tables 1 and 2 depicting the phytosociological analysis of trees and shrubs revealed the presence of 43 trees and 20 shrub species in the area belonging to 41 families and 52 genera. However, the studies carried out in the nearby regions by Dangwal et

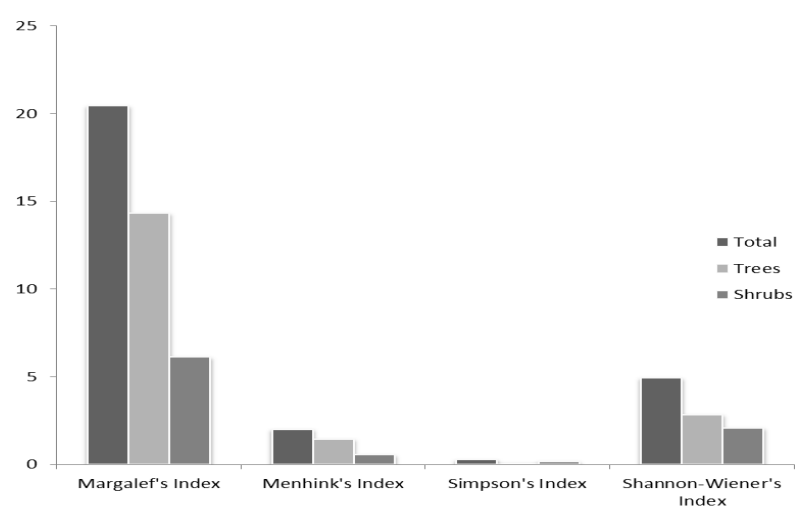

Fig. 1. Diversity indices for Trees and Shrubs in Lamberi forest range, Rajouri, $J \& K$. al.(2012 ) and Ahmed and Sharma (2014) have reported 41 woody plants ( 29 trees and 12 shrubs) and 72 woody plants (46 trees and 26 shrubs), respectively. This variation in number of species may depend upon several factor which include the local conditions with respect to micro-climate, edaphic factors, topography, sampling area, latitude/longitude, altitude and anthropogenic disturbances.

Phytosociological analysis: The phytosociological analysis carried out in the study revealed that Importance value indices (IVI) of the tree species ranged from 49.75 to 0.58 with Pinus roxburghii being the most dominant tree species while for shrubs it ranges between 18.36 to 3.014 with Carrisa opaca being the most dominant shrub species. (Table 1). The IVI, an aggregate index that summarises the density, abundance and distribution of a species, measures the overall importance of a species and gives an indication of the ecological success of a species in a particular area (Muthuramkumar and Parthasarathy, 2000). Thus IVI of a species is a function of its abundance (the number of plants within the quadrats), its dominance (influence on the other species through its shading, competition, or aggressiveness) and its frequency (contribution to the community through its distribution) (Okiror et al., 2012). Pinus roxburghii has also been reported as the dominated tree species in the Rajouri district and other adjoining areas with similar conditions (Dangwal et al., 2012 ; Nizami et al., 2009; Shaheen et al., 2011; Muhammad et al., 2012 and Kumar and Sharma, 2014) while Carrisa opaca has been reported as most dominant (Shrub) species by Dangwal et al., (2012) and Sharma and Kant (2014) in block Nowshera of district Rajouri and Kandi Shivaliks of Jammu, respectively. Almost similar trend has been reported by Sharma (2003) and Sudan (2007) for Jammu district and Mahamaya catchment, respectively.

It has also been observed that species present in and around the present study area viz. Ficus, Aegle, Psidium, Cordia, Syzygium, Zizyphus, Morus etc. and serve as source of food for the wild animals are less dominant as is reflected by their IVI values. These species are required to be prioritized for conservation and protection. Also the species which at present dominate the Chir forest viz. Pinus, Accacia, Mallotus, Dalbergia, Carissa, Justicia, Gymnosporia, Dodonaea etc.needs constant monitoring so as to conserve the structure and composition of the area.

Distribution pattern: Abundance to frequency ratio (A/F) has been calculated to assess the distribution pattern of species and depending upon the ratios, distribution may be regular $(<0.025)$, random $(0.025$ $0.05)$ and contagious $(>0.05)$. In natural conditions, contagious distribution is most common type of distribution due to significant variation in environmental conditions (Odum, 1971). Studies conducted by several workers have also reported that majority of species 
Jyoti Sharma and Anil K. Raina / J. Appl. \& Nat. Sci. 10 (1): 522 - 527 (2018)

Table 1. Phytosociological analysis of Tree species of Lamberi Forest Range, Rajouri, J\&K

\begin{tabular}{|c|c|c|c|c|c|c|c|}
\hline S.N. & Species & BA $\left(\mathrm{m}^{2} / \mathrm{ha}\right)$ & F (\%) & D $\quad$ (tree/ha) & $\mathbf{A}$ & $\mathbf{A} / \mathbf{F}$ & IVI (\%) \\
\hline 1. & Pinus roxburghii Sarg. & 20.12 & 18 & 6.76 & 18.77 & 1.04 & 49.75 \\
\hline 2. & Acacia modesta (Wall.) P.J.H. Hurter & 12.1 & 62 & 7.16 & 5.77 & 0.09 & 49.38 \\
\hline 3. & $\begin{array}{l}\text { Mallotus phillipensis } \\
\text { (Lam.) Muell. Arg. }\end{array}$ & 6.24 & 36 & 3.36 & 4.67 & 0.13 & 25.32 \\
\hline 4. & Dalbergia sissoo Roxb. & 4.6 & 44 & 2.16 & 2.45 & 0.05 & 21.30 \\
\hline 5. & Lannea coromandelica (Houtt.) Merr. & 3.66 & 26 & 1.48 & 2.85 & 0.12 & 14.42 \\
\hline 6. & Flacourtia indica (Burm.f.) Merr & 2.4 & 20 & 1.16 & 2.90 & 0.14 & 10.61 \\
\hline 7. & Ziziphus maurtiana Lam. & 1.32 & 24 & 1.28 & 2.67 & 0.11 & 10.36 \\
\hline 8. & Melia azedarach Linn. & 1.38 & 20 & 0.96 & 1.70 & 0.5 & 8.55 \\
\hline 9. & Toona ciliata M.Roemer. & 1.9 & 16 & 0.68 & 1.87 & 0.08 & 7.32 \\
\hline 10. & Cassia fistula Linn. & 1.76 & 12 & 0.6 & 2.50 & 0.12 & 6.03 \\
\hline 11. & Grewia optiva J.R Drumm. & 1.34 & 6 & 0.44 & 3.0 & 0.22 & 5.83 \\
\hline 12. & Bombax ceiba Linn. & 0.98 & 14 & 0.6 & 1.57 & 0.3 & 5.53 \\
\hline 13. & Celtis australis Linn. & 1.4 & 12 & 0.6 & 1.57 & 0.23 & 5.46 \\
\hline 14. & Bauhinia variegata Linn. & 1.14 & 10 & 0.52 & 22.0 & 0.18 & 5.08 \\
\hline 15. & Phoenix sylvestris(Linn.) Roxb. & 1.06 & 10 & 0.44 & 3.0 & 0.11 & 5.07 \\
\hline 16. & Phyllanthus emblica Linn. & 1.12 & 10 & 0.52 & 26.0 & 0.26 & 5.02 \\
\hline 17. & Morus alba Linn. & 0.94 & 12 & 0.44 & 1.83 & 0.15 & 4.96 \\
\hline 18. & Albizia lebbeck (L.) Benth. & 0.8 & 10 & 0.52 & 26.0 & 0.26 & 4.60 \\
\hline 19. & Acacia nilotica (L.) Delie. & 0.56 & 12 & 0.36 & 1.5 & 0.12 & 4.23 \\
\hline 20. & $\begin{array}{l}\text { Acacia catechu / Senegalia catechu } \\
\text { (L.f.) P.J.H. Hurter \& Mabb }\end{array}$ & 0.62 & 10 & 0.4 & 2 & 0.2 & 4.02 \\
\hline 21. & Ficus bengalensis L.s & 2.32 & 2 & 0.04 & 1 & 0.5 & 3.57 \\
\hline 22 & Zanthoxylam armatum DC. & 0.3 & 10 & 0.32 & 1.6 & 0.16 & 3.37 \\
\hline 23 & Morus serrata Roxb. & 0.46 & 10 & 0.24 & 1.2 & 0.12 & 3.34 \\
\hline 24 & Olea cuspidata Wall. ex G. Don & 0.42 & 10 & 0.2 & 1 & 0.1 & 3.17 \\
\hline 25 & Pyrus pashia Buch-Ham. ex D Don. & 0.56 & 6 & 0.36 & 3 & 0.5 & 3.01 \\
\hline 26 & Ficus auriculata Lour. & 1.74 & 4 & 0.04 & 5.5 & 0.5 & 2.81 \\
\hline 27 & Ficus religiosa Linn & 0.54 & 2 & 0.44 & 1 & 1.37 & 2.80 \\
\hline 28 & Ficus palmata Forssk. & 0.54 & 6 & 0.24 & 2 & 0.33 & 2.63 \\
\hline 29 & Ziziphus oxyphylla & 0.32 & 6 & 0.2 & 1.25 & 0.27 & 2.23 \\
\hline 30 & Ficus racemosa Roxb. & 0.24 & 6 & 0.16 & 1.33 & 0.22 & 2.00 \\
\hline 31 & Cordia myxa Linn. & 0.48 & 4 & 0.16 & 2 & 0.5 & 1.91 \\
\hline 32 & Ficus carica Linn. & 0.42 & 4 & 0.16 & 2 & 0.5 & 1.83 \\
\hline 33 & Ficus hispida L.f. & 0.36 & 4 & 0.16 & 2 & 0.5 & 1.75 \\
\hline 34 & Populous ciliata Wall ex Royle. & 0.32 & 4 & 0.16 & 2 & 0.5 & 1.70 \\
\hline 35 & Aegle marmelos Corr. & 0.3 & 4 & 0.16 & 2 & 0.5 & 1.67 \\
\hline 36 & Azadirachta indica A.Juss. & 0.28 & 4 & 0.16 & 2 & 0.5 & 1.65 \\
\hline 37 & Lagerstroemia parviflora Roxb. & 0.26 & 4 & 0.16 & 2 & 0.5 & 1.62 \\
\hline 38 & Eucalyptus tereticornis Sm. & 0.08 & 4 & 0.08 & 2 & 0.25 & 1.59 \\
\hline 39 & Psidium guajava Linn. & 0.38 & 4 & 0.08 & 1 & 1 & 1.15 \\
\hline 40 & Mangifera indica Linn. & 0.24 & 2 & 0.16 & 2 & 0.5 & 1.14 \\
\hline 41 & Sapindus mukorossi Gaertn. & 0.14 & 2 & 0.08 & 2 & 1 & 0.82 \\
\hline 42 & Syzygium cumini (L.) Skeels & 0.1 & 2 & 0.08 & 2 & 1 & 0.77 \\
\hline \multirow[t]{2}{*}{43} & Prunus persica (L.) & 0.04 & 2 & 0.04 & 1 & 0.5 & 0.58 \\
\hline & Total & 76.28 & 490 & 34.32 & & & 300 \\
\hline
\end{tabular}

$\mathrm{BA}=$ Basal area; $\mathrm{F}=$ Frequency; $\mathrm{D}=$ Density; $\mathrm{A}=$ Abundance; $\mathrm{A} / \mathrm{F}=$ Abundance to Frequency Ratio; IVI= Importance Value Index.

exhibit contagious pattern of distribution in natural vegetation and negligible species have regular distribution (Sudan, 2007; Chen et al., 2008; Bahuguna et al., 2010; Dangwal et al., 2012; Kour and Sharma, 2014, Gazal, 2015).

In the present study all the species of both trees and shrubs have been found to be contagiously distributed.

Diversity analysis: Species diversity is an index that incorporates the number of species in an area and also their relative abundance. It has been calculated on the basis of total number of individuals of species and total number of species. Typically the value of the index ranges from 1.5 (low species richness and evenness) to 3.5 (high species evenness and richness), though values beyond these limits may also be encountered. Margalef's index (Margalef, 1968) and Menhinick's Index (Menhinick, 1964) were used as a simple measures of species richness. All the indices were calculated for trees and shrubs in the study area and have been represented in Fig.1. The value of Shanon- Weiner index was found to be 3.08 for all species, with trees exhibiting 2.85 and shrubs 2.09. Whereas, the species rich- 
Jyoti Sharma and Anil K. Raina / J. Appl. \& Nat. Sci. 10 (1): 522 - 527 (2018)

Table 2. Phytosociological analysis of Shrubs species of Lamberi Forest Range, Rajouri, J\&K

\begin{tabular}{|c|c|c|c|c|c|c|c|}
\hline S. N. & Species & $\begin{array}{l}\text { BA } \\
\left(\mathrm{m}^{2} / \mathrm{ha}\right) \\
\end{array}$ & $\begin{array}{l}F \\
(\%) \\
\end{array}$ & $\begin{array}{l}\text { D (shrub/ } \\
\text { ha) }\end{array}$ & $\mathbf{A}$ & $\mathbf{A} / \mathbf{F}$ & $\begin{array}{l}\text { IVI } \\
(\%)\end{array}$ \\
\hline 1. & Carissa opaca Stapf. & 1.92 & 59 & 16.64 & 7.051 & 0.119 & 81.12 \\
\hline 2. & Justicia adhatoda Nees. & 0.336 & 36 & 12.8 & 8.89 & 0.25 & 45.06 \\
\hline 3. & Ziziphus oxyphylla Edgew. & 1.52 & 17 & 2.2 & 3.235 & 0.190 & 29.44 \\
\hline 4. & Gymnosporia royleana Wall. ex M.A. Lawson. & 0.896 & 21 & 4.48 & 5.333 & 0.254 & 28.47 \\
\hline 5. & Mimosa rubicaulis Lamk. & 1.512 & 12 & 1.32 & 2.75 & 0.229 & 25.41 \\
\hline 6. & Dodonaea viscosa Jacq. & 0.72 & 16 & 1.52 & 2.375 & 0.15 & 18.36 \\
\hline 7. & Woodfordia fruticosa (L.) kurz. & 0.092 & 8 & 3.64 & 11.37 & 1.422 & 11.79 \\
\hline 8. & Solanum erianthum D. Don & 0.58 & 5 & 0.2 & 1 & 0.2 & 9.313 \\
\hline 9. & Parthenium hysterophorus Linn. & 0.064 & 8 & 1.76 & 5.5 & 0.687 & 7.734 \\
\hline 10. & Calotropis procera (Aiton) Dryand & 0.076 & 8 & 1 & 3.125 & 0.390 & 6.363 \\
\hline 11. & Indigofera pulchella Roxb & 0.0392 & 7 & 1.16 & 4.143 & 0.592 & 5.817 \\
\hline 12. & Punica granatum Linn. & 0.292 & 4 & 0.28 & 1.75 & 0.437 & 5.692 \\
\hline 13. & Vitex negundo Linn. & 0.192 & 6 & 0.36 & 1.5 & 0.25 & 5.564 \\
\hline 14. & Ipomoea carnea Jacq. & 0.024 & 5 & 0.76 & 3.8 & 0.76 & 3.972 \\
\hline 15. & Euphorbia royleana Boiss. & 0.14932 & 3 & 0.28 & 2.333 & 0.78 & 3.599 \\
\hline 16. & Lantana camara var. aculeata (L.)Moldenke & 0.0304 & 3 & 0.76 & 6.333 & 2.111 & 3.173 \\
\hline 17. & Ricinus communis Linn. & 0.0852 & 3 & 0.36 & 3 & 1 & 3.014 \\
\hline 18. & Colebrookea oppositifolia Smith & 0.0276 & 3 & 0.4 & 3.333 & 1.111 & 2.425 \\
\hline 19. & Rosa multiflora Lindl. & 0.0484 & 3 & 0.24 & 2 & 0.667 & 2.349 \\
\hline \multirow[t]{2}{*}{20.} & Nerium indicum Mill. & 0.0116 & 2 & 0.16 & 2 & 1 & 1.326 \\
\hline & Total & 8.61 & 229 & 50.32 & & & 300 \\
\hline
\end{tabular}

$\mathrm{BA}=$ Basal area; $\mathrm{F}=$ Frequency; $\mathrm{D}=$ Density; $\mathrm{A}=$ Abundance; $\mathrm{A} / \mathrm{F}=$ Abundance to Frequency Ratio; IVI= Important Value Index.

ness values for Margalef's and Menhinick's indices are found in the range between 18.64 and 1.36 for all the species, with trees exhibiting 14.33 and 1.44 and shrubs 6.13 and 0.56 , respectively. Simpson's index of diversity for all species comes out to be 0.083 with a value of 0.10 for tree species and 0.19 for shrubs. Fig.1 clearly depicts that values of ShannonWeiner's , Margalef's, Menhinick'sand Simpson's indices were higher for trees and lower for shrubs in this forest. The tree diversity index analyzed for the study area was lower than that reported by the earlier workers like Sharma (2003) in Northern dry mixed deciduous forest of Jammu; Sharma (2008) in Birbhum watershed; Mishra et al. (2011) in Simplipal Biosphere reserve; Singh (2002) in Kalakote region of Rajouri and Dangwal et al. (2012) in Chirpine forest of Nowshera and higher than the values calculated by Rai (2007) in Mansar -Surinsar Wildlife Sanctuary, Kumar and Raina (2012) in Ratle hydro-electric project, Kishtwar and Ahmed and Sharma (2014) in Ponda watershed, Rajouri, J\&K.

\section{Conclusion}

The phytosociological studies conducted in the study area revealed the predominance of tree species like Pinus roxburghii, Acacia modesta, Mallotus philippensis, Dalbergia sissoo along with under storey species of shrubby vegetation like Carissa opaca, Justicia adhatoda, Ziziphus nummularia. The results of the secondary analysis of data revealed that species diver- sity exhibited higher values for trees and lower values for shrubs. Based on the present investigations that helped to decide on conservation priorities of both species and habitat, it is suggested that species with lower IVIs be given priority for protection and those with higher IVIs be monitored to maintain diversity. Thus, baseline information generated in the present study will help for the conservation and management of the Lamberi forest range and will also be helpful in taking future research activities for its management.

\section{REFERENCES}

Ahmed, J. and Sharma, S. (2014). Spatial pattern, diversity and phytosociological analysis of woody plant species in Ponda Watershed, Rajouri, J\&K, India. International Journal of Current Research, 6 (6) : 7022-7027.

Ahmed, M., Husain, T., Sheikh, A.H., Hussain, S.S. and Siddiqui, M.F. (2006). Phytosociology and structure of Himalayan forests from different climatic zones of Pakistan. Pakistan Journal of Botany, 38 (2) : 361-383.

Ardakani, M.R. (2004). Ecology. Tehran University Press. Bahuguna, A., Phondoni, P.C., Negi, V.S., Rawat, L.S., Maikhuri, R.K., Joshi, P.C. and Bisht, N.S. (2010). Floristic diversity and indigenous uses of forest vegetation of Dabka watershed in Indian Central Himalaya. Ethnobotanical leaflets. 14:491-510.

Chen, J., Shiyomi, M. and Yamamura, Y. (2008). Frequency distribution models for spatial patterns of vegetation abundance. Ecol. Mod. 211: 403-410

Curtis J.T (1959). The vegetation of Wisconsin: An ordination of plant communities. University of Wisconsin Press 
Madison, Wisconsin

Curtis J.T. and Cotton G. (1956). Plant Ecology Workbook: Laboratory Field Reference Manual. Burgess Publishing Co., Minnesota.

Curtis J.T. and McIntosh R.P. (1950). The interrelations of certain analytic and synthetic phytosociological characters. Ecology. 31: 434-455.

Dangwal, L.R., Singh, T., Singh, A. and Sharma, A. (2012). Plant diversity assessment in relation to disturbances in subtropical chirpine forest of the western Himalaya of district Rajouri, J\&K, India. International Journal of Plant, Animal and Environmenal Sciences. 2(2): 206213.

Dhaulkhandi, M., Dobhal, A., Bhatt, S. and Kumar, M. (2008). Community structure and regeneration potential of natural forest site in Gangotri, India. Journal of Basic and Applied Sciences. 4(1): 49-52.

Gairola, S., Rawal, R. S. and Todaria, N. P (2008). Forest vegetation patterns along an altitudinal gradient in subalpine zone of West Himalaya, India. African Journal of Plant Science. 2 (6) :42-48.

Gairola, S., Sharma, C.M., Ghildiyal, S. and Suyal, S. (2011).Tree species composition and diversity along an altitudinal gradient in moist tropical montane valley slopes of the Garhwal Himalaya, India. Forest Science and Technology. 7(3): 91-102.

Gazal, S. (2015) Phytodiversity, community structure and soil characteristics of Ramnagar Wildlife Sanctuary, Jammu. Ph.D Thesis submitted to University of Jammu, Jammu, J\&K, India.

Gurarni, D., Arya, N., Yadava, J. and Ram, J. (2010). Studies on plant biodiversity of pure Pinus roxburghii Sarg. Forest and mixed pine-oak forest in Uttarakhand Himalaya. New York Science Journal. 3(8):1-5.

Ilorkar, V.M. and Khatri, P.K. (2003). Phytosociological Study of Navegaon National Park, Maharashtra. Indian Forester. 129(3): 377-387.

Kharkwal, G. (2009). Qualitative analysis of tree species in evergreen forests of Kumaun Himalaya. African Journal of Plant Science. 4(4): 23-28.

Kharkwal, G. and Rawat, Y.S. (2010). Structure and composition of vegetation in subtropical forest of Kumaun Himalaya. African Journal of Plant Science. 4(4): 116121.

Kour, I. (2001). Phytodiversity and impact of tourism on the vegetation of Trikuta Hills (J\&K). Ph.D Thesis submitted to University of Jammu, Jammu, J\&K, India.

Kour, K. and Sharma, S. (2014). Diversity and phytosociological analysis of tree species in sacred groves of Vijaypur block, Samba (J\&K). International Journal of Science and Research. 3(6): 859-862.

Kumar, D and Sharma, S. (2014). Diversity and distribution of plant species in Mehari watershed of Doongi Block, Rajouri, J\&K. Indian Journal of Researrh. 3(3): 75-77.

Kumar, R. and Raina, A.K. (2012). Phytosociology and species diversity in the catchment of Ratle hydro-electric project, District Kishtwar -J\&K (India). Environment Conservation Journal. 13(3): 141-145,

Magurran A.E. (1988). Ecological diversity and measurement. Princeton University Press, Princeton.

Margalef, R. (1968). . Perspective in ecological theory. University of Chicago Press, Chicago.

Menhinick, E. F. (1964). A comparison of some species diversity indices applied to sample of field insects. Ecology. 45: 858-862.

Mishra, R.K., Mishra, P.K., Upadhyay, V.P. and Mohanty R.C. (2011). Ecological Problem of Tree Species in Protected Ecosystems of Orissa, India. Journal of environmental biology. 32(1): 111-116.

Muhammad, S.A., Malik, Z.H., Malik, N.Z. and Sadia, M. A. (2012). The position of Pinus roxburghii in the forests of Kotli hills, Azad Jammu and Kashmir. African Journal of Plant Science. 6(3): 106-112.

Muthuramkumar, S. and Parthasarathy, N. (2000). Alpha diversity of lianas in a tropical evergreen forest in the Anamalais, Western Ghats, India. Journal of conservation biogeography. 6(1): 1- 14 .

Nizami, S.M., Mirza, S.N., Livesley, S., Arndt, S., Fox, J.C., Khan, I.A. and Mahmood, T. (2009). Estimation carbon stocks in sub-tropical pine (Pinus roxburghii) forest of Pakistan. Pakistan Journal of Agriculture Science. 46(4): 266-270.

Odum, E.P. (1971). Fundamentals of Ecology. $3^{\text {rd }}$ ed. W.B. Saunders Company, Philadelphia.

Okiror, P., Chono, J., Nyamukuru, A., Lwanga, J.S., Sasira, P. and Diogo, P.(2012) Variation in Woody Species Abundance and Distribution in and around Kibale National Park, Uganda. ISRN Forestry .vol. 2012, PP:1-9.

Phillips, E.A. (1959). Methods of vegetation study. Henry Holt and Co., New York.

Rai, A. (2007). Studies on Phanerogam Diversity of MansarSurinsar Wild-life Sanctuary, J\&K. Ph.D. Thesis submitted to University of Jammu, Jammu, J\&K, India.

Rawat, V.S. and Chandhok, A. (2009). Phytosociological analysis and distribution patterns of tree spcies-A case study from Govind Pashu Vihar, National Park, Uttarakhand. New York Science Journal. 2(4): 58-63.

Reddy, C. S. and Ugle, P. (2008). Tree species diversity and distribution patterns in tropical forest of Eastern Ghats, India: a case study. Life Science Journal. 5(4): 87-93.

Shaheen, H., Qureshi, R.A. and Shinwari, Z.K. (2011). Structural diversity, vegetation dynamics and anthropogenic impact on lesser Himalayan subtropical forests of Bagh district, Kashmir. Pakistan Journal of Botany. 43 (4): 1861-1866.

Shaheen, H., Ullah, Z., Khan, S. M., and Harper, D. M. (2012) Species composition and community structure of western Himalayan moist temperate forests in Kashmir. Forest Ecology and Management. 278:138-145.

Shannon, C.E and Weiner, W. (1949) . The Mathematical Theory of communication. University Illinois Press, Urbana.

Sharma, N. (2003). Biodiversity characterization at Landscape Level in Jammu District of J\&K (Western Himalayas) using Remote Sensing and GIS. Ph.D. Thesis submitted to University of Jammu, Jammu, J\&K, India.

Sharma, N. and Kant, S. (2014). Vegetation structure, floristic composition and species diversity of woody plant communities in sub tropical kandi Siwaliks of Jammu, J\&K, India. International Journal of Basic and Applied Sciences, 3(4): 382-391

Sharma, N. and Raina, A.K. (2013). Composition, structure and diversity of tree species along an elevation gradient in Jammu province of North- Western Himalyas, Jammu and Kashmir, India. Journal of Biodiversity and Environmental Science. 3(10): 12-23.

Sharma, S. (2008). Conservation and management of natural 
Jyoti Sharma and Anil K. Raina / J. Appl. \& Nat. Sci. 10 (1): 522 - 527 (2018)

resources in Birhun watershed, J\&K, using Remote Sensing and GIS Techniques. D.Phil, Thesis submitted to H.N.B. Garhwal University.

Sharma, S., Sharma, R.C. and Kant, S. (2008). Assessment of biotic interference and ecological degradation in Birhum watershed, Jammu and Kashmir, Environment and Ecology. 26(3): 1539-1544.

Simpson, E.H. (1949). Measurement of diversity. Nature. 163:688.

Singh, J. (2002). Phytodiversity of Kalakote Range (Rajouri,
$\mathrm{J} \& \mathrm{~K})$ and Impact of mining and nomadism on the vegetation. Ph.D. Thesis submitted to University of Jammu, Jammu, J\&K, India.

Sudan, J. (2007). Phytodiversity and Socio-economic study of Mahamaya Catchment, Jammu, J\&K. Ph.D. Thesis submitted to University of Jammu, Jammu, J\&K, India.

Timilsina, N., Ross, M. S. and Heinen, J. T.(2007). A community analysis of sal (Shorea robusta) forests in the western Terai of Nepal. Forest Ecology and Management. 241(1-3):223-234. 